\title{
BIODEGRADABILITY OF CASSAVA EDIBLE BIOPLASTICS IN LANDFILL AND PLANTATION SOIL
}

\author{
Isroi $^{1}$, Guntarti Supeni ${ }^{2}$, Deden D. Eris ${ }^{1}$, and Agustina Arianita Cahyaningtyas ${ }^{2}$ \\ ${ }^{1}$ Indonesian Research Institute for Biotechnology and Bioindustry \\ Jalan Taman Kencana No 1, Bogor, Postcode 16128, Indonesia \\ ${ }^{2}$ Center for Chemical and Packaging \\ JI. Balai Kimia No.1, RT.7/RW.9, Pekayon, Ps. Rebo, Kota Jakarta Timur, Daerah Khusus Ibukota \\ Jakarta Postcode 13710, Indonesia \\ E-mail : isroi93@gmail.com
}

Received : 15 Januari 2018; revised : 26 Februari 2018; accepted : 28 Maret 2018

\begin{abstract}
BIODEGRADABILITY OF CASSAVA EDIBLE BIOPLASTICS IN LANDFILL AND PLANTATION SOIL.

Biodegradation research of the edible bioplastic from cassava starch by carbon dioxide analysis has not been widely reported. This research aimed to evaluate biodegradability of edible bioplastic made from cassava starch by using two natural inoculums i,e landfill and plantation soil. The edible bioplastics used in this study were bioplastic with and without hydrophobic liquid. Biodegradation test of the bioplastic was then compared to HDPE plastic. The test was conducted in the glass jar for 60 days. The carbon dioxide generated from the biodegradation process was absorbed by $0.1 \mathrm{~N}$ sodium hydroxide and titrated with $0.1 \mathrm{~N} \mathrm{HCl}$. There was no carbon dioxide released from the HDPE plastic during the test. Biodegradation of the bioplastic in plantation soil was higher than in landfill soil. Biodegradation rate of the bioplastic in landfill soil was $0.201 \mathrm{mg} \mathrm{CO}_{2} / \mathrm{day}_{\text {and }}$ $0.249 \mathrm{mg} \mathrm{CO}_{2} /$ day for bioplastic without and with hydrophobic liquid, respectively. Biodegradation rate of the bioplastic in plantation soil was $0.604 \mathrm{mg} \mathrm{CO} /$ day and $0.424 \mathrm{mg} \mathrm{CO} /$ day for bioplastic without and with hydrophobic liquid, respectively. Complete biodegradation of the bioplastic in landfill soil was predicted in 431 days and 366 days for bioplastic without and with hydrophobic liquid, respectively. In another hand, complete biodegradation of the bioplastic in plantation soil predicted in 151 days and 201 days for bioplastic without and with hydrophobic liquid, respectively. Microbes population in the soil could be affected the biodegradation rate of the bioplastics.
\end{abstract}

Keywords : Biodegradability, Bioplastic, Cassava starch, Natural inoculum

\begin{abstract}
ABSTRAK
BIODEGRADABILITAS BIOPLASTIK EDIBLE DARI TEPUNG SINGKONG DI TANAH PEMBUANGAN AKHIR SAMPAH DAN PERKeBUNAN. Penelitian uji biodegradabilitas bioplastik edible dari tepung singkong dengan analisis karbondioksida belum banyak dilaporkan. Tujuan dari penelitian ini adalah mengevaluasi biodegrabilitas bioplastik edible dari tepung singkong dengan menggunakan dua inoculum alami yaitu tanah dari lokasi pembuangan akhir sampah dan perkebunan. Bioplastik edible yang digunakan dalam penelitian ini adalah bioplastik dengan dan tanpa penambahan cairan hidrofobik. Uji biodegradasi bioplastik kemudian dibandingkan dengan plastik HDPE. Uji dilakukan di dalam botol kaca selama 60 hari. Karbon dioksida yang dihasilkan dari proses biodegradasi akan diserap oleh larutan natrium hidroksida 0,1 N dan dititrasi dengan $\mathrm{HCl} 0,1 \mathrm{~N}$. Plastik HDPE tidak melepaskan karbon dioksida selama pengujian. Biodegradasi bioplastik di tanah perkebunan lebih tinggi daripada di tanah pembuangan akhir. Biodegradasi bioplastik di tanah pembuangan akhir adalah 0,201 $\mathrm{mg}$ $\mathrm{CO}_{2} /$ hari dan 0,249 $\mathrm{mg} \mathrm{CO}$ /hari untuk bioplastik tanpa dan dengan cairan hidrofobik. Biodegradasi bioplastik di lahan perkebunan adalah 0,604 $\mathrm{mg} \mathrm{CO} /$ hari dan 0,424 $\mathrm{mg} \mathrm{CO}$ /hari untuk bioplastik tanpa dan dengan cairan hidrofobik. Biodegradasi total bioplastik di tanah pembuangan akhir diperkirakan membutuhkan waktu 431 hari dan 366 hari untuk bioplastik tanpa dan dengan cairan hidrofobik. Di sisi lain, biodegradasi total bioplastik di lahan perkebunan diperkirakan membutuhkan waktu 151 hari dan 201 hari untuk bioplastik tanpa dan dengan cairan hidrofobik. Perbedaan laju biodegradasi bioplastik dipengaruhi oleh populasi mikroba di dalam inokulum.
\end{abstract}

Kata kunci : Biodegradabilitas, Bioplastik, Pati singkong, Inokulum alami

\section{INTRODUCTION}

The research and development of biodegradable bioplastics formed with raw materials from agricultural origin have more attention and suitable with the concept of 
ecologically safe sustainable industrial development. Various natural biopolymers obtained from the agricultural product or byproduct are proposed for the formulation of biodegradable and edible bioplastic, such as polysaccharide, protein, and lipids (Fakhoury et al. 2012; Guerrero et al. 2011; Lopattananon et al. 2012). Some advantages of this agricultural product are fully biodegradable and renewable, non-toxic for the environment, human and animal. When food-grade ingredients are used in the formulation of the bioplastic, it can be edible. Edible bioplastic is a thin film of edible materials applied to the food product that plays a vital role in their preservation, distribution, and marketing (Matta et al. 2015). Edible bioplastic (EB) is a pre-formed, thin layer, made of an edible material, which, once formed, can be placed on or between food components (McHugh 2000).

Among the agro-polymers that can be formed from edible bioplastic, cassava starch is a potential source, especially in Indonesia. Indonesia is the third cassava (Manihot esculenta) producer in the world (FAO 2017). Indonesia's cassava production in 2015 was 21.8 million tonnes (BPS 2017). Cassava is one of the most important food crops in the humid tropics. A typical composition of the cassava root is moisture $(70 \%)$, starch $(24 \%)$, fiber $(2 \%)$, protein $(1 \%)$, and other substances including minerals (3\%) (Tonukari 2004). Cassava starch extracted from the cassava root and has been used in edible bioplastic production (Bersaneti et al. 2016; Piñeros-Hernandez et al. 2017).

Biodegradability is one of the main properties of the edible bioplastic, that could be biodegraded by enzymes action of the organism, such as fungi, bacteria, and yeast. Biodegradability of the bioplastic could be tested by several methods, such as aerobic composting or biodegradation, enzymatic saccharification, and anaerobic digestion (Morse et al. 2011; Liu et al. 2016; Emadian, Onay, and Demirel 2017). End-products of the biodegradation process are $\mathrm{CO}_{2}, \mathrm{H}_{2} \mathrm{O}$, and heat under aerobic condition or hydrocarbons, methane, and biomass under anaerobic conditions (Medina Jaramillo et al. 2016). Biodegradation performance of the bioplastic under aerobic degradation evaluated by measuring the $\mathrm{CO}_{2}$ released during the biodegradation test. The evolved $\mathrm{CO}_{2}$ is trapped in a solution, e.g., sodium hydroxide $(\mathrm{NaOH})$ or captured in absorption columns filled with the pellet of soda lime and soda talc (Castro-Aguirre et al. 2017; Briassoulis and Degli Innocenti 2017). The cumulative amount of the $\mathrm{CO}_{2}$ evolved during the biodegradation represent the biodegradability of the bioplastic (Ahn et al. 2011).

Our research team developed an edible bioplastic made of cassava starch and to be used for food packaging. Hydrophobic liquid (modified vegetable oil) was used to improve moisture barrier property of the bioplastic (Song and Zheng 2008). However, although all components in the bioplastic are edible and biodegradable, the biodegradability of the edible bioplastic has not tested. Meanwhile, biodegradation study of the edible bioplastic from cassava starch by carbon dioxide analysis has not been widely reported. This research aimed to examine the biodegradability of the bioplastic in plantation soil and landfill soil as natural inoculum. Degradation of the bioplastic in aerobic condition by microorganism would release carbon dioxide as degradation result. The carbon dioxide was trapped in the sodium hydroxide solution and measured by titration methods.

\section{MATERIALS \& METHODS}

\section{Materials}

Cassava starch was prepared from local edible cassava root. Cassava root was peeled and washed before shredded become a pulp slurry. Starch was extracted from the cassava pulp slurry by squeezing. Fiber and starch removed by screening and the starch then decanted and dried. The starch stored at room temperature and keep in dry before use. The plasticizer used in this study was food grade glycerol and obtained from the local market. Acetic acid used was analytical grade. Cannola oil obtained from local market used as a hydrophobic liquid.

\section{Preparation of the Edible Bioplastic}

Cassava edible bioplastics were prepared by casting technique (Fakhoury et al. 2012). The gelatinized starch solution with glycerol as a plasticizer was prepared as follow, $40 \mathrm{gr}$ of dried cassava starch (moisture content $<5 \%$ ), distilled water, and glycerol were then added, respectively, to obtain 6 wt\% of starch dispersion with 1 wt\% glycerol. Subsequently, the solution was mechanically stirred at high speed followed by the acetic acid acidification to $1 \%(\mathrm{v} / \mathrm{v})$. Modified vegetable oil added to obtain $0.1 \mathrm{wt} \%$ into the solution as a hydrophobic liquid. An edible film without hydrophobic liquid marked as Cassava Bioplastic A and edible film with hydrophobic liquid marked as Cassava Bioplastic B. The mixture was then heated to the gelatinization temperature of starch $\left( \pm 70^{\circ} \mathrm{C}\right)$ and continuously stirred at this temperature until completely gelatinized. The mixture solution was cast onto acrylic sheet mold $(20 \mathrm{~mm} \times 20 \mathrm{~mm}$ ) with a wet thickness of $5 \mathrm{~mm}$. The cast sheet was dried at ambient temperature. The bioplastic sheets were cut into $1 \mathrm{~cm}$ to $1 \mathrm{~cm}$ pieces. All bioplastic samples keep in a desiccator to maintain the humidity before use. 


\section{Fungal Resistance Test}

Fungal resistance test determined according to ASTM G21 (ASTM 1990). Fungal isolates used in the test were Aspergillus niger, Penicillium sp, Chaetomium globosum, Glicladium virens, and Aerobasidium pullulans. The fungal isolates were grown in PDA (Potato Dextrose Agar) medium for one week. The spore suspensions were aseptically centrifuged three times and the supernatant liquids discarded. The spores obtained from each of the fungi were diluted with a sterile mineral solution to avoid any residue from the culture medium. The final inoculum was a mixture of five fungal spore suspension.

Bioplastic samples were cut into a circle shape with $50 \mathrm{~mm}$ in diameter. The bioplastic samples placed aseptically into sterilized Nutrient-Salt Agar (NA) in a petri dish. $1 \mathrm{~mL}$ of the spore suspension (contain $10^{6}$ propagules) poured aseptically onto the bioplastic samples and spread carefully using glass rod. The petri dish was then incubated at room temperature for one week. The test experiment was done in five replications. Visual quantification of fungal growth on the material surface determined by observed growth on bioplastic samples and rated between 0 (no growth) and 4 (massive growth $60 \%$ to complete coverage).

\section{Biodegradation Test}

The inoculums used in the biodegradation test were local landfill soil and plantation soil. The landfill soil obtained from Galuga, Bogor West Java and plantation soil collected from cocoa plantation soil at Dramaga, Bogor West Java. The inoculum collected from the topsoil $5 \mathrm{~cm}$ to $10 \mathrm{~cm}$ in deep. The soil was screened to remove debris and organic material. The soil keeps in container and room temperature to maintain the humidity and microbial activity.

Biodegradation test was conducted in $300 \mathrm{~mL}$ glass bottle arrangement as Figure 1 according to the reference (Khaswar et al. 2008). HDPE plastic used as a reference sample in the test. $100 \mathrm{gr}$ of each the inoculum soil was placed into the samples bottle. Each bioplastic and reference plastics samples $( \pm 0.1 \mathrm{gr})$ were placed and buried in the soil. A bottle without bioplastic or plastic samples was used as a control test to corrected the carbon dioxide released during the test. Carbon dioxide was channeled using a tube to the other bottle with $50 \mathrm{~mL}$ of $0.1 \mathrm{~N}$ sodium hydroxide. The carbon dioxide would react with the sodium hydroxide. All experiment held in duplo experiment and at room temperature $\left(28{ }^{\circ} \mathrm{C}\right)$ for 60 days. The moisture content of the soil is maintained as much as possible by spraying sterile water when needed. Every three days the sodium hydroxide was replaced and analyzed for carbon dioxide.

\section{Carbon Dioxide Analysis}

The carbon dioxide entrapped in the sodium hydroxide determined by titration with $0.1 \mathrm{~N}$ hydrochloric acid solution. Phenolphthalein (PP) used as first indicator and methyl orange as the second indicator. Amount of hydrochloric acid needed to neutralize the solution into pink is proportional to the carbon dioxide releases during the biodegradation test.

The theoretical $\mathrm{CO}_{2}$ content $\left(\mathrm{ThCO}_{2}\right)$ produced by total oxidation of the material is calculated from :

$$
\mathrm{ThCO}_{2}=\mathrm{C} \cdot \frac{4}{1}
$$

where $C$ is the total carbon content of the samples materials.

Net $\mathrm{CO}_{2}$ released from the samples calculated by :

Net $\mathrm{CO}_{2}$ sample $=\left(\mathrm{CO}_{2}\right)_{\text {materials }}-\left(\mathrm{CO}_{2}\right)_{\text {blank }}$

The negative value presented as zero value or no $\mathrm{CO}_{2}$ released from the sample. Cumulative $\mathrm{CO}_{2}$ day by day from the net $\mathrm{CO}_{2}$ represent biodegradation of the samples. Carbon dioxide accumulation curve was used to determine the biodegradation rate by regression analysis. Biodegradation rate was predicted by the slope of the regression curve and/or regression equation. Total biodegradation time was calculated from the regression equation.

The degree of mineralization is then expressed by :

$$
\text { Mineralization }=\frac{\left[\begin{array}{ll}
C_{a}
\end{array}\right] \mathrm{m} \quad a-\left[C_{2}\right]^{b}}{\operatorname{ThC} 2}
$$

where $\left[\mathrm{CO}_{2}\right]_{\text {materials }}$ is the amount of $\mathrm{CO}_{2}[\mathrm{mg}]$ measured in the test vessel, and $\left[\mathrm{CO}_{2}\right]_{\text {blank }}$ the quantity in the negative control vessel, which contained no carbon source.

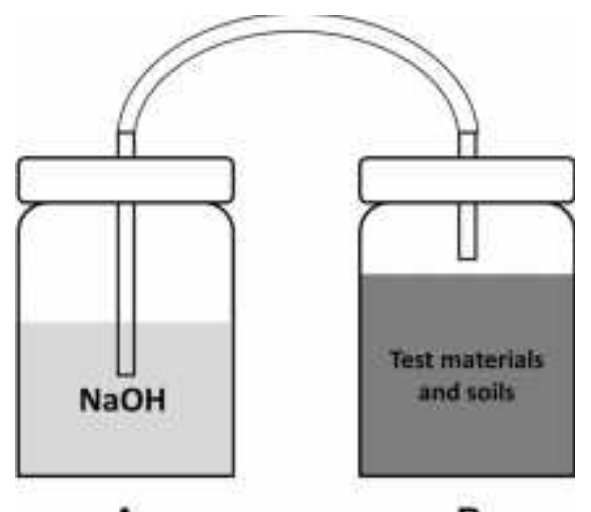

A

B

Figure 1. Experimental setup of the biodegradation test, (A) carbon dioxide trap with $0.1 \mathrm{~N}$ $\mathrm{NaOH},(B)$ test material and plantation soil

RESULT AND DISCUSSION 


\section{General Properties of Bioplastic}

The visual appearance of the edible bioplastic film is presented in Figure 2, and their properties are shown in Table 1. Bioplastic A and Bioplastic $B$ are almost equal in appearance and properties. The thickness of the bioplastic samples around $100 \mu \mathrm{ma}$. Bioplastic A is slightly thicker than Bioplastic B. These two bioplastic samples have similar tensile strength and transparencies. The tensile strength of the bioplastic samples is around $30 \mathrm{kgf} / \mathrm{cm}^{2}$ and good enough for food wrapping application. Most ingredient to make these edible bioplastics are similar, therefore carbon content of the samples is not significantly different.

Addition of the hydrophobic liquid did not effect on the organic content (presented as carbon content) and tensile strength of the bioplastic. In other hands, the hydrophobic liquid addition to the bioplastic could improve moisture barrier of the bioplastic, which presented as water vapor transmission rate (WVTR). The edible film made from starch has a low moisture barrier because cassava starch naturally is hydrophilic (Colivet and Carvalho 2017). These low moisture barrier properties restrict the application of the starch-based bioplastic. Glycerol also has hydrophilic properties. Reported in other studies which observed an increase of the moisture content of the bioplastic following an increasing in the glycerol concentration (Alves et al. 2007; López, García, and Zaritzky 2008). WVTR value of the edible bioplastic without hydrophobic liquid addition was $25.90 \mathrm{~g} / \mathrm{m}^{2} / \mathrm{hr}$, otherwise WVTR value for edible bioplastic with hydrophobic liquid addition was $8.58 \mathrm{~g} / \mathrm{m}^{2} / \mathrm{hr}$. An effort to increase the moisture barrier of the edible film has been made by adding various lipid compounds, such as fatty acid, lipid, gum, and wax (Acosta et al. 2015; Kim et al. 2015; Rodrigues et al. 2014; Ma et al. 2012). Adding a hydrophobic compound into bioplastic matrix could increase the moisture barrier and reduce the WVTR value of the bioplastic.

Functional groups of the hydrophobic liquid used in this experiment are mostly similar to starch and glycerol. Adding a small amount of the hydrophobic liquid in the edible bioplastic also did not affect the functional groups as shown in the FTIR spectra in Figure 3.

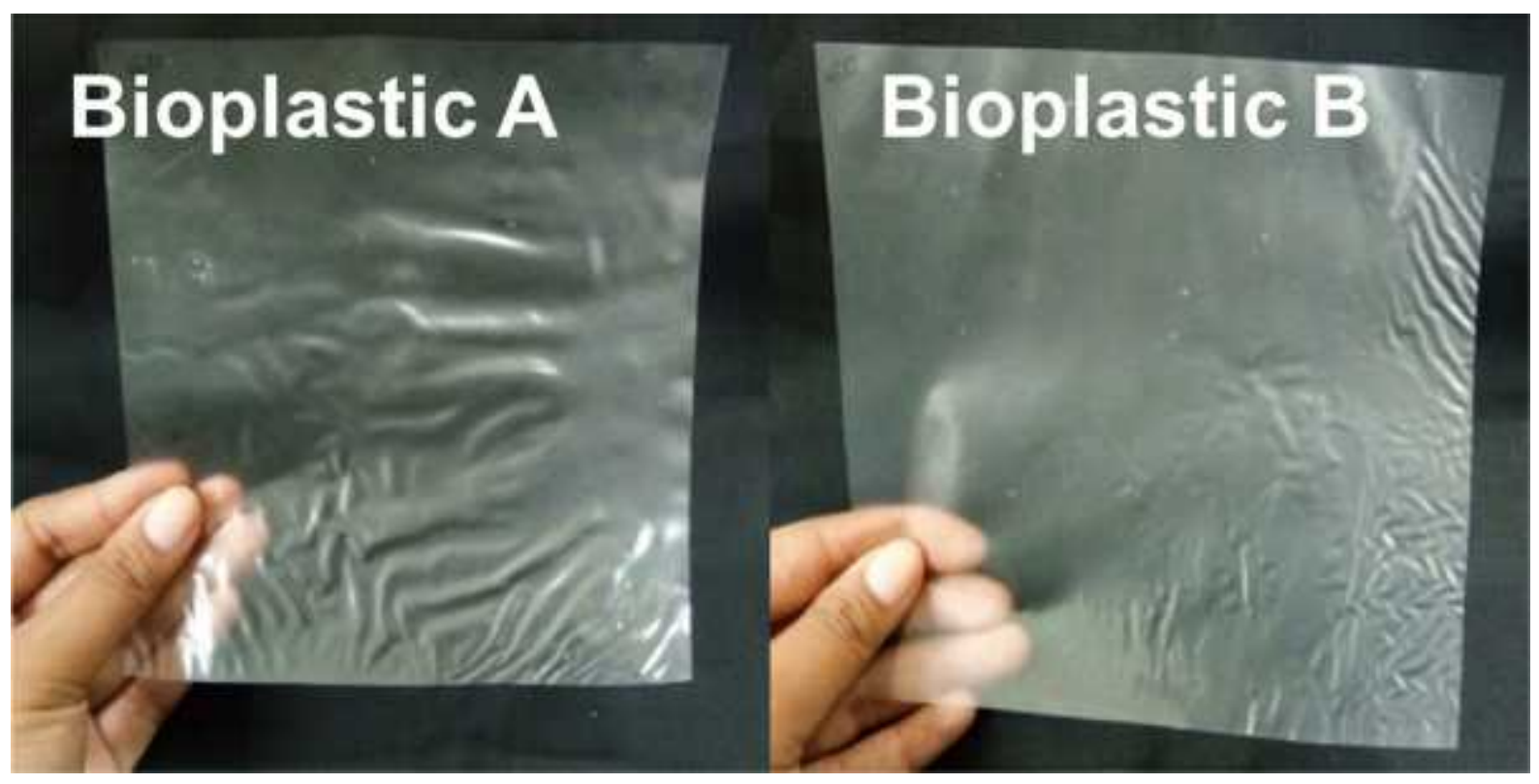

Figure 2. Visual appearances of the edible bioplastic film

Table 1. Properties of the edible bioplastic film

\begin{tabular}{lll}
\hline Properties & Bioplastic A & Bioplastic B \\
\hline Thickness $(\mu \mathrm{m})$ & $102 \pm 19$ & $88 \pm 8$ \\
Total carbon content $(\%)$ & 40.332 & 41.454 \\
Tensile strength $\left(\mathrm{kgf} / \mathrm{cm}^{2}\right)$ & $30.08 \pm 2.15$ & $31.60 \pm 2.15$ \\
Water vapour transmission rate $(\mathrm{WVTR})\left(\mathrm{g} / \mathrm{m}^{2} / \mathrm{hr}\right)$ & $25.90+0.84$ & $8.58+0.85$ \\
\hline
\end{tabular}

Fungal Resistance 
The fungal resistance test uses several fungi that known as common soil fungi in minimal medium that is deficient only in carbon (Lucas et al. 2008). Consequently, the growth of the fungi is dependent on the utilization of the bioplastic samples as a carbon source. The bioplastic samples that could be overgrown by the fungi shown that the example is potentially biodegradable. This method is faster than biodegradation test using composting methods and could be useful for rapid evaluation of the biodegradability.

Fungal growth on the bioplastic samples was shown in Figure 4. All the samples, including filter paper as reference material, were covered by the fungal growth. Hence the score for all samples is four. All fungi used in this experiment are common fungi that active in biodegradation of organic material and could be grown in minimal medium (Anastasi, Varese, and Filipello Marchisio 2005). Aspergillus sp, Trichoderma sp, and Penicillium sp have been investigated in the biodegradation of the bioplastic in a natural environment (Emadian, Onay, and Demirel 2017). The fungal mycelium overgrew the filter paper in one week after inoculation. The filter paper used as control samples to evaluate the growth of the fungal and shows that the fungi are in excellent condition. Similar results were obtained in the bioplastic samples. All bioplastic samples were covered by the fungal mycelium few days after inoculation. Fungal growth was faster on the bioplastic samples than in the filter paper. Starch is containing monosaccharides as building block as well as cellulose in the filter paper. The monosaccharide configuration and arrangement in cellulose and starch are in various carbon linkage, resulted in different physical and chemical characteristics (Aggarwal, Dollimore, and Heon 1997). Carbon linked in the starch is weaker and more efficiently to degraded by microorganism than cellulose.

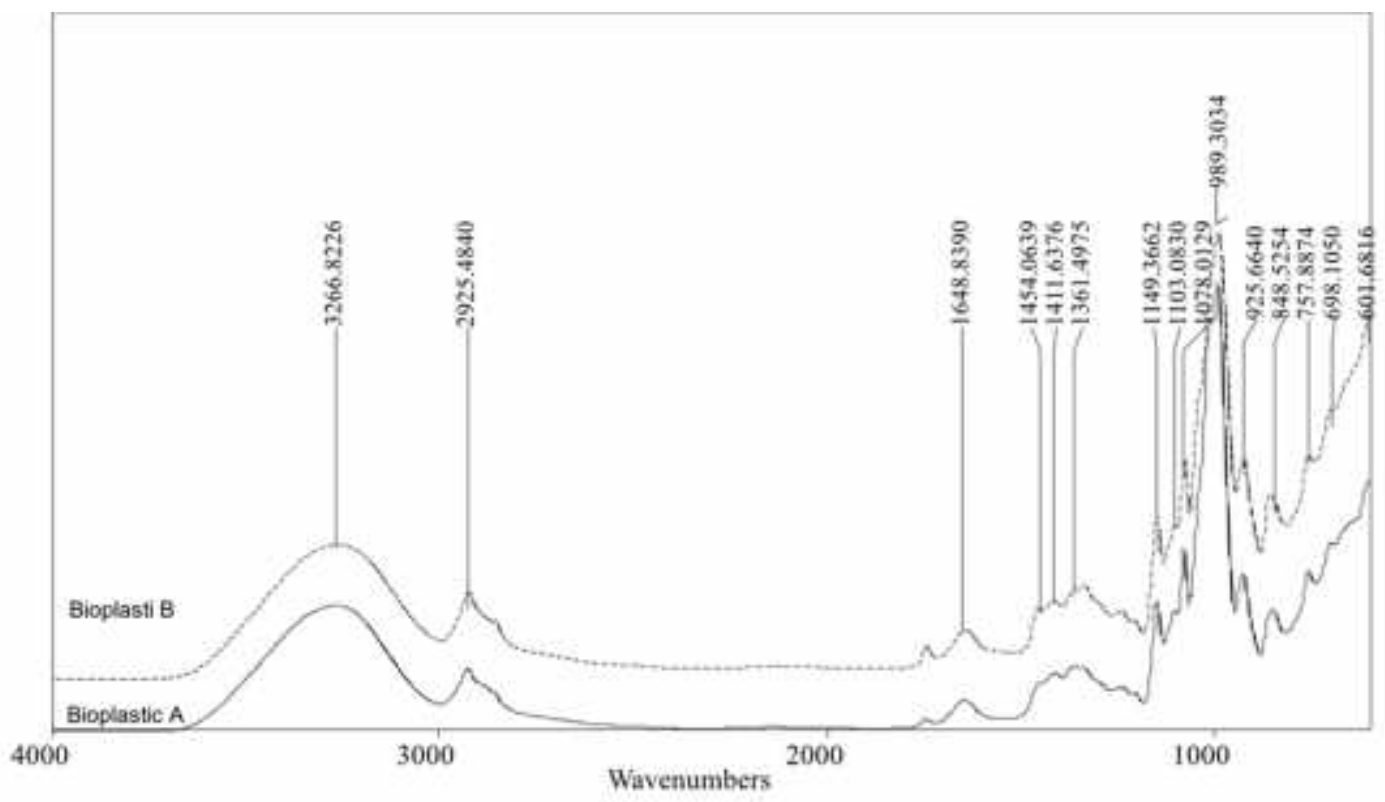

Figure 3. Spectrum FTIR of the edible bioplastic film

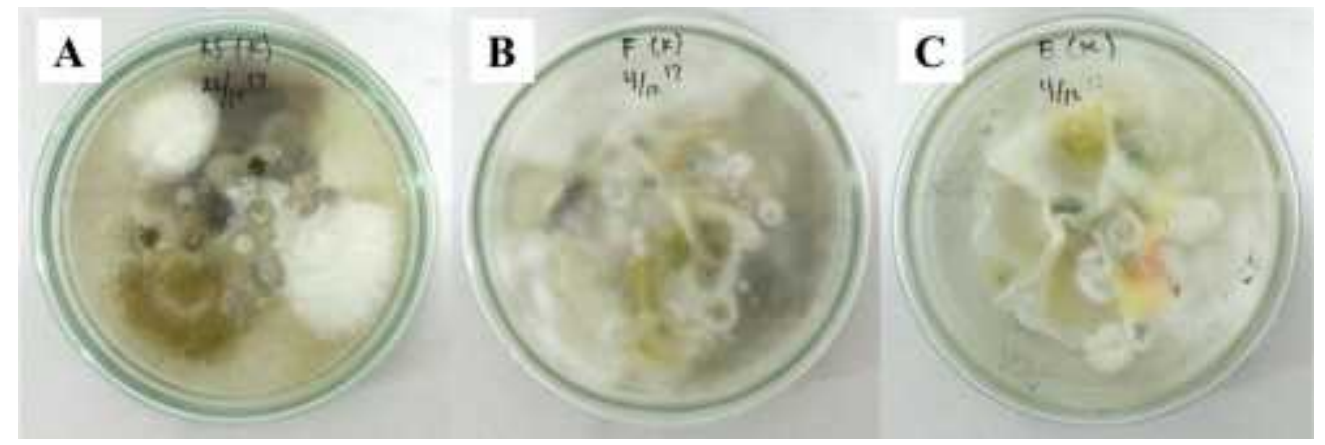

Figure 4. Fungal growth on samples of the fungal resistance test : A. filter paper (control), B. Bioplastic A, and C. Bioplastic B. 


\section{Bioplastic Biodegradation Pattern}

The microbial population in the plantation soil was higher than in the landfill soil. Microbial populations were $2.1 \times 10^{6} \mathrm{cfu}$ soil for landfill soil and $4.6 \times 10^{6} \mathrm{cfu}$ for plantation soil. There was entire microbe colony including bacteria, fungi, and actinomycetes. These microorganisms used organic carbon as an energy source. In aerobic condition, the organic material, such as bioplastics, would be bio-degraded into $\mathrm{CO}_{2}$, $\mathrm{H}_{2} \mathrm{O}$, and produce heat (Adhikari et al. 2016). The carbon dioxide released is fluctuated time by time and shown in Figure 5 for landfill soil and Figure 6 for plantation soil. Carbon dioxide from the blank experiment, without bioplastic samples, was carbon dioxide released from the original organic carbon source in the soil. Carbon dioxide released from the HDPE plastic was similar to or below the blank experiment. It is mean that almost no $\mathrm{CO}_{2}$ released from the HDPE plastic. Carbon dioxide released from the bioplastic experiments were some of the carbon dioxide released from the bioplastic and the original organic carbon source.
Higher $\mathrm{CO}_{2}$ evolution was three days after inoculation for landfill and plantation soil. Higher $\mathrm{CO}_{2}$ amount in landfill soil was $5.54 \mathrm{mg}$ and 4.48 $\mathrm{mg}$ for Bioplastic A and Bioplastic B, respectively. Whereas, the higher $\mathrm{CO}_{2}$ amount in plantation soil were $2.64 \mathrm{mg}$ and $3.08 \mathrm{mg}$ for Bioplastic A and Bioplastic B, respectively. The $\mathrm{CO}_{2}$ released than gradually reduced until the end of the evaluation. In landfill soil, $\mathrm{CO}_{2}$ evolution was significantly declined after 9 days and continued declined less than $2 \mathrm{mg}$ until 60 days. Evolution of the $\mathrm{CO}_{2}$ in plantation soil was declined after 18 days and almost stable until 60 days.

$\mathrm{CO}_{2}$ evolution from the blank experiment of landfill soil was higher than $\mathrm{CO}_{2}$ evolution from the blank experiment of plantation soil in an early stage of the test, resulted in a higher sum of $\mathrm{CO}_{2}$ in landfill soil than in plantation soil. However, the $\mathrm{CO}_{2}$ evolution from the bioplastic samples in plantation soil was higher than in landfill soil. Microorganism community in the plantation soil was more active to degrade the bioplastic samples than in landfill soil.

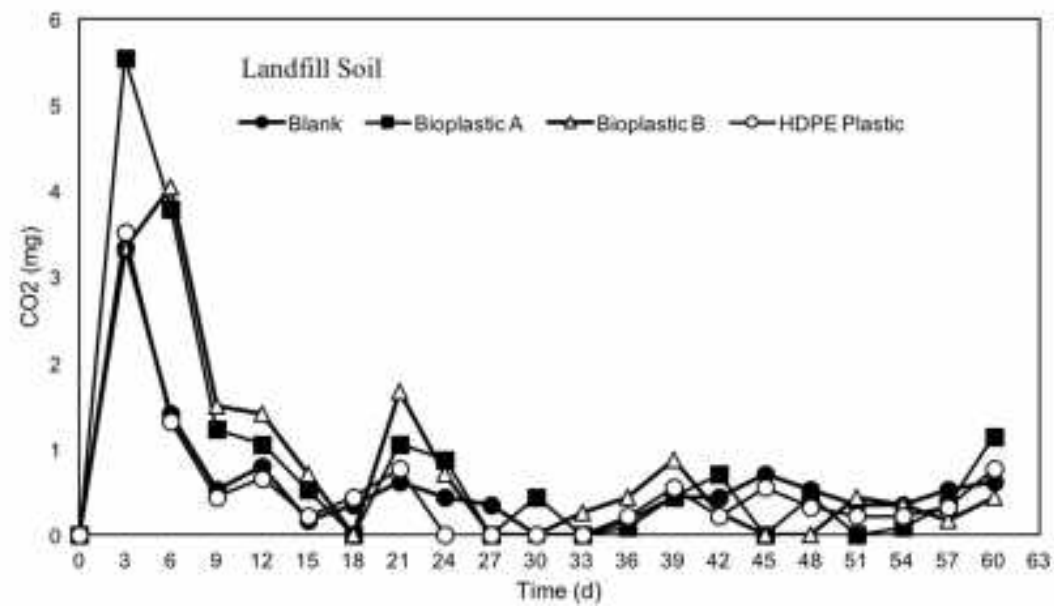

Figure 5. Carbon dioxide $(\mathrm{mg})$ released during the biodegradation test in landfill soil

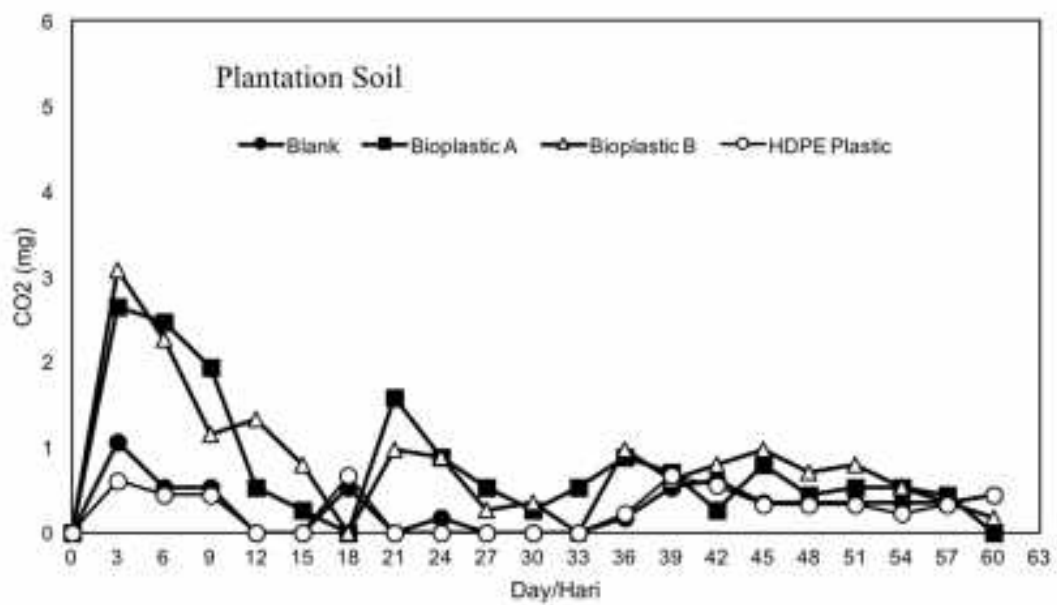

Figure 6. Carbon dioxide $(\mathrm{mg})$ released during the biodegradation test in plantation soil 
Microbial diversity of the landfill soil is lower than in plantation soil. Landfill soil is contaminated by xenobiotic compound and has an anaerobic microbial community (Perez-Leblic et al. 2010; Lloyd-Jones and Lau 1998). Plantation soil is richer in microbial diversity and mostly aerobic microorganism. Microbial populations in the plantation soil are responsible for the biodegradation of organic material by aerobic degradation (Ndaw et al. 2009). Microbial diversity was not analyzed in this study, but the different population in the soil samples could represent different diversity in the soil samples. Different $\mathrm{CO}_{2}$ profile from the landfill soil and plantation soil caused by different microbial population and variety of the soil source.

\section{Biodegradation Rate}

Biodegradation of the bioplastic samples were represented as cumulative of the carbon dioxide released from the bioplastic samples and subtracted by control experiment. Biodegradation of the bioplastic samples are shown in Figure 7 and Figure 8. There is distinct $\mathrm{CO}_{2}$ profile of the landfill and plantation soil. Carbon dioxide accumulation from the landfill soil was become stable three weeks after inoculation and carbon dioxide accumulation of the Bioplastic B was lower than Bioplastic A. Carbon dioxide evolution from the plantation soil was still increasing until 60 days. Total $\mathrm{CO}_{2}$ accumulation in landfill soil was $8.0 \mathrm{mg}$ and 7.1 $\mathrm{mg}$ for Bioplastic A and Bioplastic B, respectively. Whereas, Total $\mathrm{CO}_{2}$ accumulation in plantation soil was $14.08 \mathrm{mg}$ and $11.41 \mathrm{mg}$ for Bioplastic A and Bioplastic B, respectively.

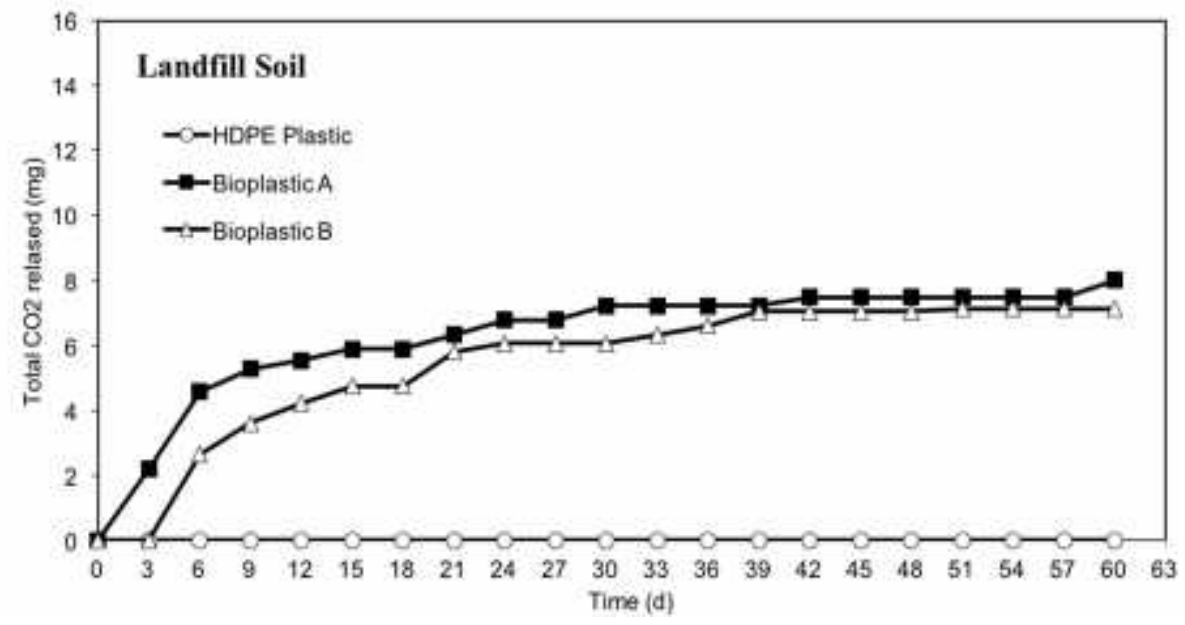

Figure 7. Total accumulation of $\mathrm{CO}_{2}$ released during biodegradation test in landfill soil : a) Bioplastic A, edible bioplastic without hydrophobic liquid addition, b) Bioplastic B, edible bioplastic with hydrophobic liquid addition, and c) HDPE plastic

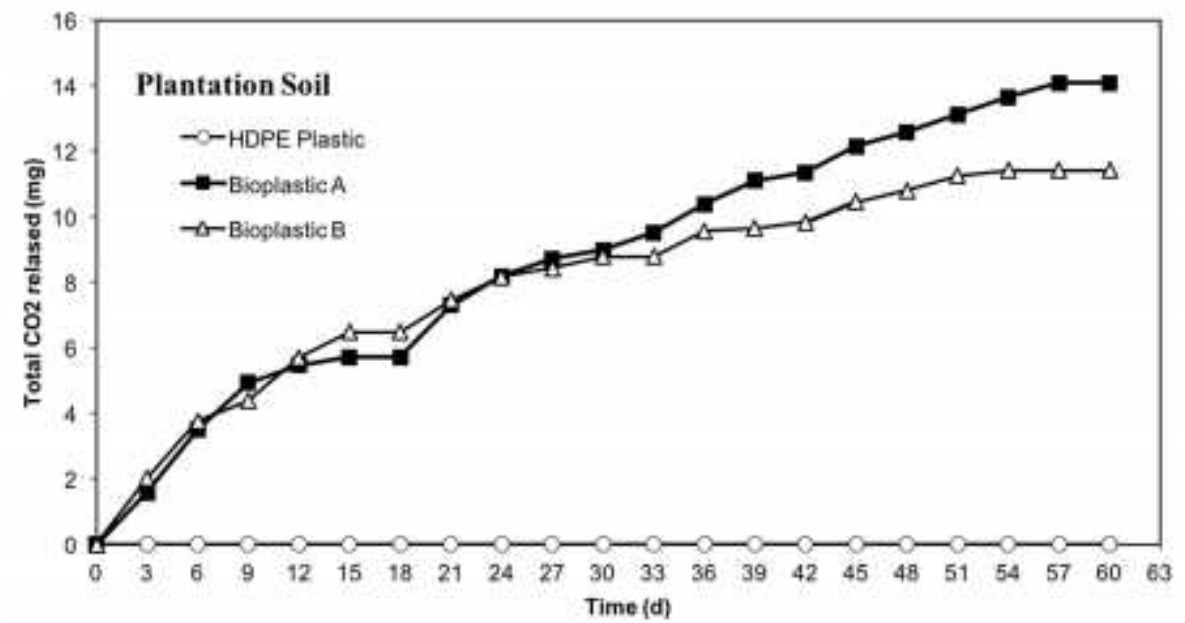

Figure 8. Total accumulation of $\mathrm{CO}_{2}$ released during biodegradation test in plantation soil : a) Bioplastic $\mathrm{A}$, edible bioplastic without hydrophobic liquid addition, b) Bioplastic B, edible bioplastic with hydrophobic liquid addition, and c) HDPE plastic 
Mineralization of the bioplastic samples in the inoculum soil was presented in Figure 9 and Figure 10. These figures were used to predict the percentage of the degradation process. Biodegradation of the bioplastic in the landfill soil was seemed stagnant after three weeks of the biodegradation test. The biodegradation rate was meager at this stage. Only around $5 \%$ of the Bioplastic A was degraded from 30 days until 60 days. Bioplastic B was lower degraded than Bioplastic A in the landfill soil. Mineralization of the bioplastic samples in the plantation soil was higher than in the landfill soil as presented in Figure 10. Biodegradation rate was almost constant until the end of the biodegradation test. There was no significant difference in biodegradation pattern between Bioplastic $\mathrm{A}$ and Bioplastic B. It was around $10 \%$ of the bioplastic samples were degraded during the test.

Carbon dioxide evolution as result of the biodegradation of the bioplastic samples was dependent on the microbial activities in the soil and abiotic condition, such as moisture content and temperature. The microbial population in the plantation soil was higher than in the landfill soil. Therefore $\mathrm{CO}_{2}$ evolved in plantation soil was higher than landfill soil. Higher microbial population in plantation soil could be affected by higher organic material and less pollutant content in plantation soil than in landfill soil. Beside evolved $\mathrm{CO}_{2}$, biodegradation of the bioplastic also produce $\mathrm{H}_{2} \mathrm{O}$ and heat that could be evaporated by the $\mathrm{H}_{2} \mathrm{O}$ and reduced the moisture. Microbial activity depends on the moisture content of the soil. Microbial activity will decrease when the moisture decreasing resulted in a decrease in $\mathrm{CO}_{2}$ during the biodegradation.

Adding hydrophobic liquid into bioplastic formulation in a certain amount could reduce water vapor permeability and increase water barrier of the bioplastic (Adjouman et al. 2017). Low water permeability also decreased in moisture content of the bioplastic. Moisture content is a dominant factor impacting microbial activity during biodegradation of the organic materials (Liang, Das, and McClendon 2003). Reducing the moisture content would reduce the biodegradation activity. This phenomenon explained the lower biodegradation rate of the Bioplastic B samples than the Bioplastic A.

Biodegradation rate of the bioplastic samples predicted by regression analysis of the data (Table 2). Biodegradation rate of the bioplastic samples in landfill soil were $0.201 \mathrm{mg}$ $\mathrm{CO}_{2} /$ day and $0.249 \mathrm{mg} \mathrm{CO} /$ day for Bioplastic $\mathrm{A}$ and Bioplastic $\mathrm{B}$, respectively. Although biodegradation rate of the Bioplastic $B$ was higher than Bioplastic $A$, biodegradation of the Bioplastic B was started at 3 days after inoculation. Biodegradation rate of the bioplastic samples in plantation soil were $0.604 \mathrm{mg}$ $\mathrm{CO}_{2} /$ day and $0.424 \mathrm{mg} \mathrm{CO} /$ day for Bioplastic $\mathrm{A}$ and Bioplastic B, respectively. In general, biodegradation rate in plantation soil was higher than in landfill soil.

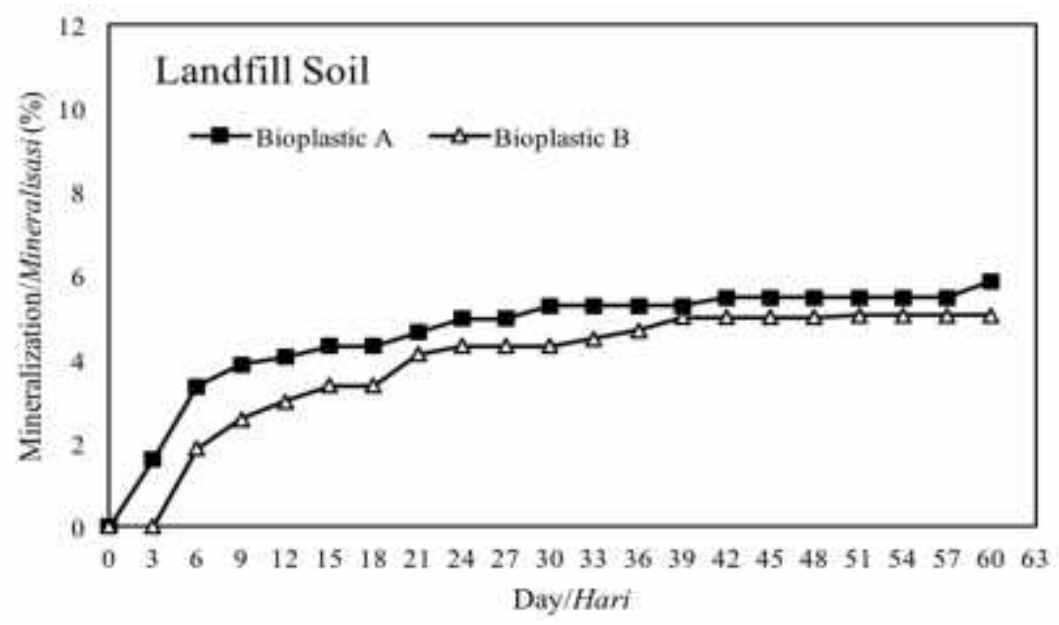

Figure 9. Degradation curves of edible bioplastic in the landfill soil : a) Bioplastic A, edible bioplastic without hydrophobic liquid addition dan b) Bioplastic B, edible bioplastic with hydrophobic liquid addition. 


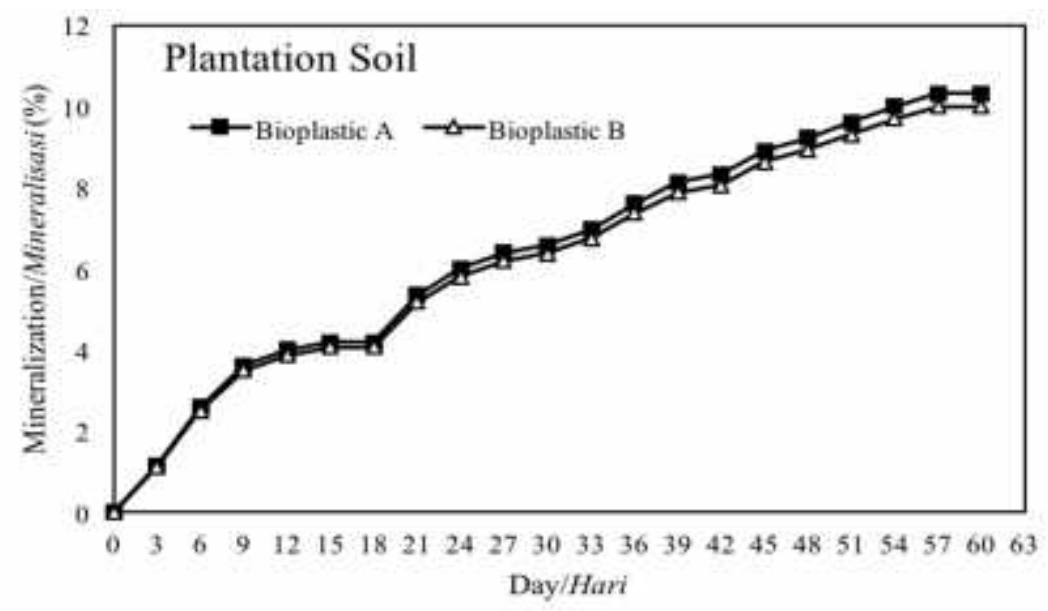

Figure 10. Degradation curves of edible bioplastic in the plantation soil : a) Bioplastic A, edible bioplastic without hydrophobic liquid addition dan b) Bioplastic B, edible bioplastic with hydrophobic liquid addition.

Table 2. Resume of the biodegradation test of the edible bioplastic samples

Theoretical Biodegradation rate $\left(\mathrm{mg} \mathrm{CO}_{2} /\right.$ day $)$
$\mathrm{CO}_{2}(\mathrm{mg})$

\begin{tabular}{lll}
\hline Landfill soil & & \\
Bioplastic A & 136.467 & 0.201 \\
Bioplastic B & 140.887 & 0.249 \\
& & \\
Plantation soil & & 0.604 \\
Bioplastic A & 136.467 & 0.424 \\
Bioplastic B & 140.887 & \\
\hline
\end{tabular}

\section{CONCLUSION}

Throughout fungal resistance test and $\mathrm{CO}_{2}$ evaluation during biodegradation test, it was demonstrated that edible bioplastic made from cassava starch could be degraded by a microorganism in landfill soil and plantation soil. All bioplastic samples were easier to overgrown by fungi as shown in ASTM G21 test. Fungal resistance test could be used as a rapid determination of the bioplastic biodegradability. However, adding a small amount of hydrophobic liquid into the bioplastic could increase the moisture barrier properties of the bioplastic, in other hand did not affect other properties of the bioplastic. The bioplastic samples could be biodegraded by indigenous microbial population from landfill soil and plantation soil. The biodegradation in the plantation soil was higher than in the landfill soil as higher as a microbial population in the soil.

\section{ACKNOWLEDGEMENTS}

The authors would like to thank to the Ministry of Research, Technology and Higher Education of the Republic of Indonesia for financial support of this study by Insinas Riset Pratama programe with contract number: 19/INS/PPK/E/E4/2017. The authors also thank to Siti Ropikoh, Mirta Mariandani, Miar Trikanthi and Nurul for their contribution in biodegadation analysis.

\section{REFERENCES}

Acosta, S., A. Jiménez, M. Cháfer, C. G. Martínez, and A. Chiralt. 2015. "Physical Properties and Stability of Starch-Gelatin Based Films as Affected by the Addition of Esters of Fatty Acids." Food Hydrocolloids $49 . \quad$ : 135-43. doi:10.1016/j.foodhyd.2015.03.015. 
"Degradation of Bioplastics in Soil and Their Degradation Effects on Environmental Microorganisms." Journal of Agricultural Chemistry and Environment 5 (1) : 23-34. doi:10.4236/jacen.2016.51003.

Adjouman, Y. D., C. Nindjin, F. A. Tetchi, A.-C. Dalcq, N. G. Amani, and M. Sindic. 2017. "Water Vapor Permeability of Edible Films Based on Improved Cassava (Manihot Esculenta Crantz) Native Starches." Journal of Food Processing \& Technology 8. Los Angels: 665. doi:10.4172/21577110.1000665 .

Aggarwal, P., D. Dollimore, and K. Heon. 1997. "Comparative Thermal Analysis Study of Two Biopolymers, Starch and Cellulose." Journal ofThermal Analysis 50: 7-17. doi:10.1007/bf01979545.

Ahn, H. K., M. S. Huda, M. C. Smith, W. Mulbry, W. F. Schmidt, and J. B. Reeves. 2011. "Biodegradability of Injection Molded Bioplastic Pots Containing Polylactic Acid and Poultry Feather Fiber." Bioresource Technology $102 \quad$ (7) : 4930-33. doi:10.1016/j.biortech.2011.01.042.

Alves, V. D., S. Mali, A. Beléia, and M. V. E. Grossmann. 2007. "Effect of Glycerol and Amylose Enrichment on Cassava Starch Film Properties." Journal of Food Engineering 78 (3): 941-46. doi:10.1016/j.jfoodeng.2005.12.007.

Anastasi, A., G. C. Varese, and V. Filipello Marchisio. 2005. "Isolation and Identification of Fungal Communities in Compost and Vermicompost." Mycologia 97 (1): 33-44. doi:10.3852/mycologia.97.1.33.

ASTM. 1990. "ASTM G21-90: Stanard Practice for Determining Resistence of Synthetic Polymeric Materials to Fungi." American Society for Testing Materials.

Bersaneti, G. T., J. Mantovan, A. Magri, S. Mali, and M. A. P. C. Celligoi. 2016. "Edible Films Based on Cassava Starch and Fructooligosaccharides Produced by Bacillus Subtilis Natto CCT 7712." Carbohydrate Polymers 151.: 1132-38. doi:10.1016/j.carbpol.2016.06.081.

BPS. 2017. "Produksi Ubi Kayu Menurut Propinsi (Ton), 1993-2015." Badan Pusat
Statistik.

Briassoulis, D., and F. D. Innocenti. 2017. "Standards for Soil Biodegradable Plastics." In Soil Degradable Bioplastics for a Sustainable Modern Agriculture, 139-68. doi:10.1007/978-3-662-5413026 .

Castro-Aguirre, E., R. Auras, S. Selke, M. Rubino, and T. Marsh. 2017. "Insights on the Aerobic Biodegradation of Polymers by Analysis of Evolved Carbon Dioxide in Simulated Composting Conditions." Polymer Degradation and Stability 137: 251-71.

doi:10.1016/j.polymdegradstab.2017.01.0 17.

Colivet, J., and R. A. Carvalho. 2017. "Hydrophilicity and Physicochemical Properties of Chemically Modified Cassava Starch Films." Industrial Crops and Products 95: 599-607. doi:10.1016/j.indcrop.2016.11.018.

Emadian, S. M., T. T. Onay, and B. Demirel. 2017. "Biodegradation of Bioplastics in Natural Environments." Waste Management 59: 526-36. doi:10.1016/j.wasman.2016.10.006.

Fakhoury, F. M., S. M. Martelli, L. C. Bertan, F. Yamashita, L. H. I. Mei, and F. P. C. Queiroz. 2012. "Edible Films Made from Blends of Manioc Starch and Gelatin Influence of Different Types of Plasticizer and Different Levels of Macromolecules on Their Properties." LWT - Food Science and Technology 49 (1): 149-54. doi:10.1016/j.lwt.2012.04.017.

FAO. 2017. "Crops Production." FAOSTAT.

Guerrero, P., Z. A. N. Hanani, J.P. Kerry, and K. de la Caba. 2011. "Characterization of Soy Protein-Based Films Prepared with Acids and Oils by Compression." Journal of Food Engineering 107 (1) : 41-49. doi:10.1016/j.jfoodeng.2011.06.003.

Guilbert, S., and N. Gontard. 2005. "AgroPolymers for Edible and Biodegradable Films: Review of Agricultural Polymeric Materials, Physical and Mechanical Characteristics." In Innovations in Food Packaging, 263-76. doi:10.1016/B978012311632-1/50048-6. 
Performance in a Model Frozen-Food System." Journal of Food Science 54 (6): 1390-92.

Khaswar, S., K. Setyowati, and A. A. Khoiri. 2008. "The Effect of Plastisizer Additions (Polyethylene Glycol 400 and Dimethyl Phtalate) on the Biodegradation Process of Bioplastics Poly-B-Hydroxyalkanoat in Liquid Media with Limited Air." Jurnal Teknologi Pertanian 4 (1): 4-14.

Kim, S. R. B., Y. G. Choi, J. Y. Kim, and S. T. Lim. 2015. "Improvement of Water Solubility and Humidity Stability of Tapioca Starch Film by Incorporating Various Gums." LWT-Food Science and Technology 64 (1) : 475-82. doi:10.1016/j.Iwt.2015.05.009.

Liang, C., K. C. Das, and R. W. McClendon. 2003. "The Influence of Temperature and Moisture Contents Regimes on the Aerobic Microbial Activity of a Biosolids Composting Blend." Bioresource Technology $86 \quad$ (2) : 131-37. doi:10.1016/S0960-8524(02)00153-0.

Liu, W. W., J. Xue, B. J. Cheng, S. W. Zhu, Q. $\mathrm{Ma}$, and $\mathrm{H}$. Ma. 2016. "Anaerobic Biodegradation, Physical and Structural Properties of Normal and High-Amylose Maize Starch Films." International Journal of Agricultural and Biological Engineering $9 \quad(5)$ : doi:10.3965/j.jjabe.20160905.2005.

Lloyd-Jones, G., and P. C. K. Lau. 1998. "A Molecular View of Microbial Diversity in a Dynamic Landfill in Quebec." FEMS Microbiology Letters 162 (2) : 219-26. doi:10.1111/j.1574-6968.1998.tb13002.x.

Lopattananon, N., C. Thongpin, and N. Sombatsompop. 2012. "Bioplastics from Blends of Cassava and Rice Flours: The Effect of Blend Composition." International Polymer Processing 27 (3): 334-40. doi:10.3139/217.2532.

López, O. V., M. A. García, and N. E. Zaritzky. 2008. "Film Forming Capacity of Chemically Modified Corn Starches." Carbohydrate Polymers 73 (4): 573-81. doi:10.1016/j.carbpol.2007.12.023.

Lucas, N., C. Bienaime, C. Belloy, M. I. Queneudec, F. Silvestre, and J. E. N. Saucedo. 2008. "Polymer Biodegradation: Mechanisms and Estimation Techniques A Review." Chemosphere 73 (4): 429-42. doi:10.1016/j.chemosphere.2008.06.064.

Ma, W., C. H. Tang, S. W. Yin, X. Q. Yang, Q.
Wang, F. Liu, and Z. H. Wei. 2012. "Characterization of Gelatin-Based Edible Films Incorporated with Olive Oil." Food Research International 49 (1) : 572-79. doi:10.1016/j.foodres.2012.07.037.

Matta, F., S. Maria, T. Caon, J. Ignacio, L. Helena, I. Mei, and F. M. Fakhouri. 2015. "Edible Films and Coatings Based on Starch/gelatin: Film Properties and Effect of Coatings on Quality of Refrigerated Red Crimson Grapes." Postharvest Biology and Technology 109 : 57-64. doi:10.1016/j.postharvbio.2015.05.015.

McHugh, T. H. 2000. "Protein-Lipid Interactions in Edible Films and Coatings." Nahrung/Food 44 (3): 148-51. doi:10.1002/15213803(20000501)44:3<148::AIDFOOD148>3.0.CO;2-P.

Medina Jaramillo, C., T. J. Gutiérrez, S. Goyanes, C. Bernal, and L. Famá. 2016. "Biodegradability and Plasticizing Effect of Yerba Mate Extract on Cassava Starch Edible Films." Carbohydrate Polymers 151: 150-59. doi:10.1016/j.carbpol.2016.05.025.

Morse, M. C., Q. Liao, C. S. Criddle, and C. W. Frank. 2011. "Method for Anaerobic Biodegradation of Bioplastics." Google Patents.

Ndaw, S. M., A. C. G. Rodrigues, E. F. G. Rodrigues, K. R. N. Sales, and A. S. Rosado. 2009. "Relationships between Bacterial Diversity, Microbial Biomass, and Litter Quality in Soils under Different Plant Covers in Northern Rio de Janeiro State, Brazil." Canadian Journal of Microbiology $55 \quad$ (9) : 1089-95. doi:10.1139/w11-082.

Perez-Leblic, M. I., A. Turmero, M. Hernandez, A. J. Hernandez, J. Pastor, A. S. Ball, J. Rodriguez, and M. E. Arias. 2010. "Influence of Xenobiotic Contaminants on Landfill Soil Microbial Activity and Diversity." J Environ Manage. doi:S03014797(10)00213-6 [pii]10.1016/j.jenvman.2010.07.017.

Piñeros-Hernandez, D., C. M. Jaramillo, A. L. Córdoba, and S. Goyanes. 2017. "Edible Cassava Starch Films Carrying Rosemary Antioxidant Extracts for Potential Use as Active Food Packaging." Food Hydrocolloids 63 : 488-95. doi:10.1016/j.foodhyd.2016.09.034. 
C. Azeredo. 2014. "Influence of Cassava Starch and Carnauba Wax on Physical Properties of Cashew Tree Gum-Based Films." Food Hydrocolloids 38 : 147-51. doi:10.1016/j.foodhyd.2013.12.010.

Song, Y., and Q. Zheng. 2008. "Improved Tensile Strength of Glycerol-Plasticized Gluten Bioplastic Containing Hydrophobic
Liquids.” Bioresource Technology 99 (16): 7665-71. doi:10.1016/j.biortech.2008.01.075.

Tonukari, N. J. 2004. "Cassava and the Future of Starch." Electronic Journal of Biotechnology 7 (1) : 5-8. doi:10.4067/S0717-34582004000100003. 